\title{
Absorption, Translocation and Metabolism of Orbencarb in Soybean Plants
}

\author{
Mitsumasa Ikeda, Tadaaki Una and Chojiro Tomizawa* \\ Life Science Research Institute, Kumiai Chemical Industry Co., Ltd., \\ Kikugawa-cho, Ogasa-gun, Shizuoka 439, Japan \\ * National Institute of Agro-Environmental Sciences, \\ Yatabe-machi, Tsukuba-gun, Ibavaki 305, Japan
}

(Received September 13, 1985)

\begin{abstract}
The absorption, translocation and metabolism of ${ }^{14} \mathrm{C}$-orbencarb [S-(2-chlorobenzyl-U-14 $\left.\mathrm{C}\right)$ $N, N$-diethylthiocarbamate] were studied in soybean plants. The absorption and translocation of radioactivity derived from ${ }^{14} \mathrm{C}$-orbencarb, which was applied onto the soil surface at a rate of $5 \mathrm{~kg} / \mathrm{ha}$, increased as the plants grew. The plants at the flowering, green seed and mature stages absorbed $0.8,9.3$ and $9.1 \%$ of the applied radioactivity, respectively. The radioactivity absorbed was highest in the leaves and lowest in the seeds. ${ }^{14} \mathrm{C}$-Orbencarb was rapidly transformed to water-soluble metabolites in the plant. The major metabolites identified were 2-chlorobenzyl alcohol and 2-chlorobenzoic acid in both free and conjugated forms, 2-chlorobenzylsulfonic acid and methyl 2-chlorobenzylsulfone, and the minor metabolites were orbencarb sulfoxide, monodesethyl-orbencarb, didesethyl-orbencarb, $N$-ethyl- $N$-vinylorbencarb, 4-hydroxy-orbencarb, 5-hydroxy-orbencarb and methyl 2-chlorobenzylsulfoxide.
\end{abstract}

\section{INTRODUCTION}

Orbencarb [S-(2-chlorobenzyl) $N, N$-diethylthiocarbamate] is a pre-emergence herbicide which effectively controls weeds in upland fields. Since the herbicide is applied to soils, it is highly possible that some part of it penetrates into crops through the roots during the growth. This study was to elucidate the metabolic fate of the herbicide throughout the growing stages of soybean plants with the special emphasis on terminal residues in the crop products.

\section{MATERIALS AND METHODS}

\section{Chemicals}

${ }^{14} \mathrm{C}$-Orbencarb labeled uniformly at the benzene-ring was supplied by Kumiai Chemical Industry Co., Ltd. The specific activity of ${ }^{14} \mathrm{C}$ orbencarb was adjusted to $2.39 \mathrm{mCi} / \mathrm{mmol}$ with unlabeled pure orbencarb and the radiochemical purity was determined $99.8 \%$ by thin layer chromatography (TLC).

For the identification of orbencarb metabolites, the authentic compounds were synthesized by Ihara Chemical Industry Co., Ltd. and the National Institute of Agro-Environmental Sciences. Their chemical structures were confirmed by IR, NMR and MS. $R f$ values on silica gel chromatoplates $\left(60 \mathrm{~F}_{254}\right.$ with $0.25 \mathrm{~mm}$ thickness, Merck) with several solvent systems and designations of the chemicals are shown in Table 1.

\section{Plant and Soil}

Soybean, Glycine max var. EnRAY, was chosen, because it was considerably tolerant to orbencarb. A volcanic ash soil was collected at Nagano Prefectural Agricultural Experimental Station, pulverized and sieved through a 5-mesh sieve for experiments. Physicochemical properties of the soil were indicated in our previous report. ${ }^{1)}$ 


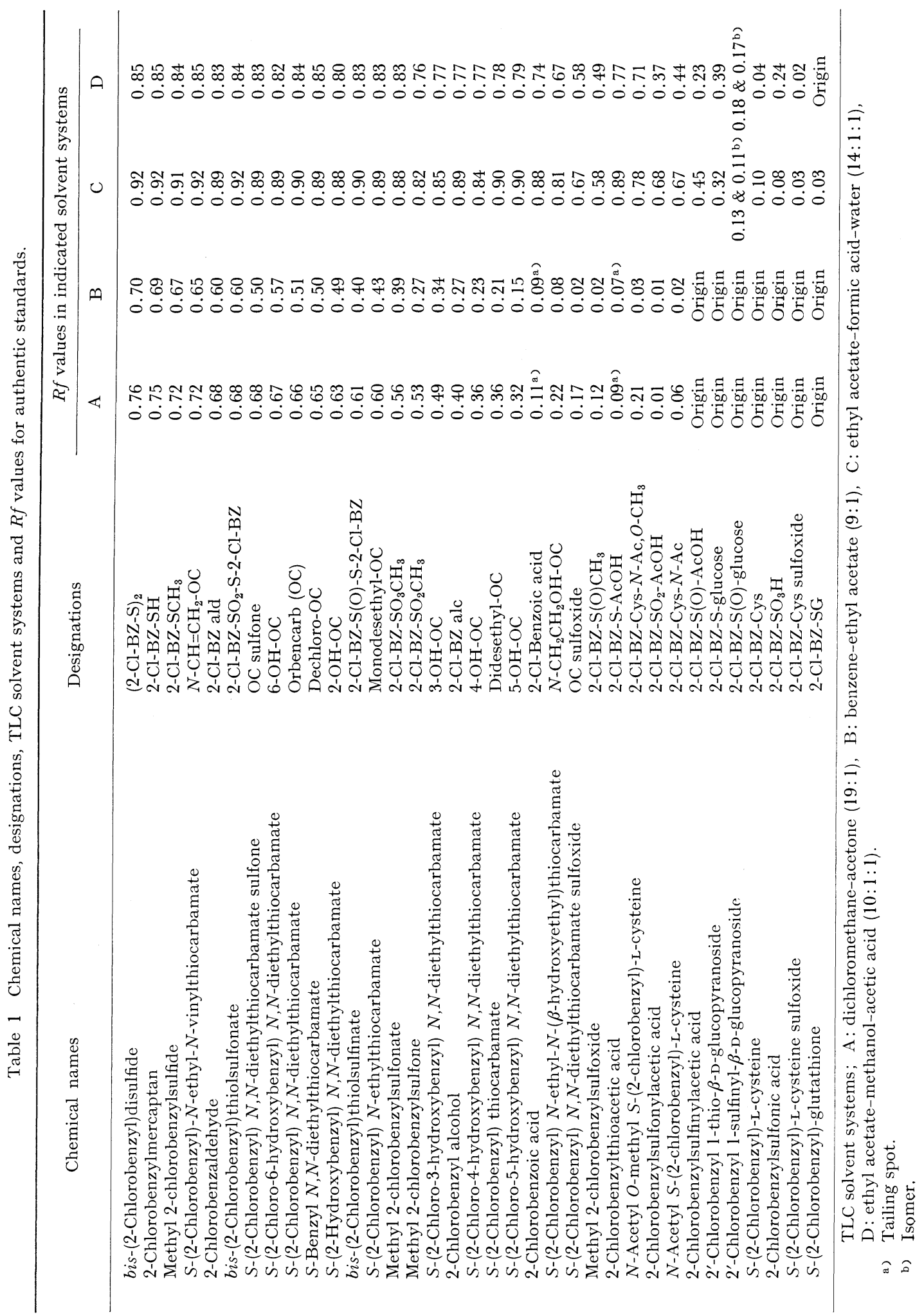




\section{Treatment of ${ }^{14} \mathrm{C}$-Orbencarb}

Unglazed pots $27 \mathrm{~cm}$ in diameter (ca. 570 $\mathrm{cm}^{2}$ in area), and $23 \mathrm{~cm}$ high were filled up with $8.5 \mathrm{~kg}$ of the soil. Six soybean seeds were planted $3 \mathrm{~cm}$ deep in each pot. $\mathrm{An}{ }^{14} \mathrm{C}$-orbencarb water emulsion of $2850 \mathrm{ppm}$ was prepared by dissolving $344.9 \mathrm{mg}(3.2 \mathrm{mCi})$ of ${ }^{14} \mathrm{C}$ orbencarb and $345 \mathrm{mg}$ of emulsifier in $120 \mathrm{ml}$ of water. Immediately after seeding, $10 \mathrm{ml}$ of the water emulsion per pot was applied onto the soil surface uniformly with a pipette, followed by $20 \mathrm{ml}$ of distilled water. The dosage corresponded to $5 \mathrm{~kg}$ orbencarb per hectare. Treated pots were kept in a laboratory. Soybean plants emerged 5 days after the treatment. Three healthy seedlings were kept in a pot with the rest discarded and grown under greenhouse conditions. During the period of growth, a suitable soil moisture was maintained by supplying water onto the soil surface.

Plants were taken $1,3,7,12,15,19,30$ (flowering stage), 62 (green seed stage) and 84 (mature stage) days after seeding.

The plants were grown in pots $15 \mathrm{~cm}$ in diameter until the fifth-true leaf stage. To observe the absorption through the leaf surface, the upper surface of the first- or fifth-true leaf was topically applied with $50 \mu \mathrm{l}$ of 2850 ppm ${ }^{14} \mathrm{C}$-orbencarb solution $(1.32 \mu \mathrm{Ci})$ by a microsyringe. To observe the absorption through the stem, the stem $2 \mathrm{~cm}$ above the soil surface was wrapped with a filter paper 2 $\mathrm{cm}$ wide and impregnated with $100 \mu \mathrm{l}$ of the water emulsion. The treated plants were kept in a greenhouse for 15 days and the plants were supplied for autoradiography.

\section{Extraction of Metabolites}

Plant samples were separated into six parts, root, stem, petiole, leaf, pod and seed, and metabolites were extracted, excluding seeds, according to the following procedure: The parts separated were cut finely with a scissors and homogenized with their 5-fold volume $(\mathrm{v} / \mathrm{w})$ of aqueous methanol (methanol-water $=$ $3: 1, \mathrm{v} / \mathrm{v}$ ) by an Ultra Turax ${ }^{\circledR}$ (Type TP 18-10, Janke \& Kunkel KG, West Germany). The homogenates were filtered and the residues were further extracted twice with fresh aqueous methanol and filtered. The filtrates were combined and concentrated in vacuo to about one-third of the original volume. The concentrates were adjusted to $\mathrm{pH} 2$ with $\mathrm{HCl}$ and extracted with dichloromethane. Immediately after extraction, the water-soluble fractions were brought back to $\mathrm{pH} 5$ with $\mathrm{NaOH}$ solution. The dichloromethane-soluble fractions were dried on anhydrous $\mathrm{Na}_{2} \mathrm{SO}_{4}$, and aliquots of the dichloromethane- and water-soluble fractions were taken into vials for radioassay. After drying, a part of the pulp residues was combusted by a Packard 306 sample oxidizer for radioassay. The extraction procedure for metabolites in seeds was modified slightly: Seeds were immersed in a mixture of methanol, chloroform and water $(3: 2: 1, \mathrm{v} / \mathrm{v})$, kept for several hours and homogenized. The homogenate was filtered and the residue was extracted again with the same solvent and filtered. The filtrates were combined, concentrated to about one-fifth of the original volume and extracted twice with $n$-hexane. The hexane extracts were combined and extracted twice with acetonitrile. After adjusted to $\mathrm{pH}$ 2 , the remaining aqueous fractions were extracted with dichloromethane and brought back to $\mathrm{pH} 5$.

After sampling the mature plants, the soils in the pots were mixed throughly. Soil samples of fifty grams were extracted three times with the aqueous methanol solution. The extracts were concentrated in vacuo, followed by the extraction with dichloromethane in the same way as for the plant materials. Soil bound residues were determined according to the combustion method by a sample oxidizer (Packard 306).

\section{Identification of Metabolites}

After dichloromethane-, acetonitrile- and water-soluble fractions were concentrated in vacuo, the authentic compounds regarded as possible metabolites were added to aliquots of the concentrates and evaporated to about 0.2 $\mathrm{ml}$ under a nitrogen stream. Co-chromatography with the authentic compounds was conducted using silica gel chromatoplates in two dimensional ways with solvent systems as shown in Table 1. Solvent systems A and B were applied to dichloromethane- and acetonitrile-soluble fractions. The chromatoplates of dichloromethane-soluble fractions below $R f$ 
value 0.25 (solvent system A) were cut off and developed again horizontally with solvent system C to separate polar metabolites (Fig. 5). Solvent systems C and D were applied to watersoluble fractions.

Radioactive metabolites on TLC plates were detected by autoradiography and authentic compounds by the absorption of UV $(254 \mathrm{~nm})$.

The metabolites in the water-soluble frac- tions and at the origin of TLC plates conducted with the dichloromethane-soluble fractions were treated with enzymes or acids. A part of the fractions was incubated with a mixture of $\beta$-glucosidase (Sigma) and cellulase (Sigma) in $1.0 \mathrm{M}$ acetate buffer, $\mathrm{pH} 5.0$. After incubated at $37^{\circ} \mathrm{C}$ for $4 \mathrm{hr}$, the incubation mixtures were adjusted to $\mathrm{pH} 2$ with $\mathrm{HCl}$ and extracted twice with dichloromethane. ${ }^{14} \mathrm{C}$-Aglycons in the

Table 2 Concentration of radioactivity in soybean seedlings after treatment of ${ }^{14} \mathrm{C}$-orbencarb (5 kg/ha, eq.) on the soil.

\begin{tabular}{lcccrrr}
\hline \multirow{2}{*}{ Plant parts } & \multicolumn{5}{c}{ ppm, ${ }^{14}$ C-orbencarb eq./fresh wt. (days after treatment) } \\
\cline { 2 - 7 } & 1 & 3 & 7 & 12 & 15 & 19 \\
\hline Root & - & - & 4.45 & 6.61 & 14.18 & 18.30 \\
Stem and hypocotyl & - & 0.11 & 7.99 & 3.17 & 7.14 & 5.24 \\
Cotyledom & 0.01 & 1.21 & 1.08 & 2.08 & 1.78 & - \\
Primary leaf & - & - & 2.40 & 4.14 & 5.95 & 7.37 \\
First true leaf & - & - & - & 1.24 & 1.86 & 2.51 \\
Second true leaf & - & - & - & - & 1.48 & 1.98 \\
Third true leaf & - & - & - & - & - & 0.99 \\
Shoot apex & - & - & - & 1.33 & 2.00 & 1.07 \\
Whole plant & 0.01 & 1.05 & 3.06 & 3.30 & 4.70 & 4.54 \\
\hline
\end{tabular}

Table 3 Distribution of radioactivity at the flowering, green seed and mature stages of the soybean plant.

\begin{tabular}{ccccc}
\hline Stages & Parts & ppm, ${ }^{14}$ C-orbencarb eq./fresh wt. & \multicolumn{2}{c}{$\%$ of applied radioactivity } \\
\hline \multirow{3}{*}{ Flowering } & Whole plant & 5.21 & 0.8 & $(100.0)$ \\
& Leaf +petiole & 4.80 & 0.5 & $(59.2)$ \\
& Stem & 2.87 & 0.1 & $(17.1)$ \\
& Root & 26.23 & 0.2 & $(23.7)$ \\
\hline \multirow{5}{*}{ Green } & Whole plant & 10.34 & 9.3 & $(100.0)$ \\
seed & Seed & 1.61 & 0.4 & $(4.8)$ \\
& Pod & 4.22 & 0.9 & $(9.3)$ \\
& Leaf & 26.47 & 5.7 & $(61.1)$ \\
& Petiole & 6.55 & 0.4 & $(4.3)$ \\
& Stem & 8.46 & 0.9 & $(9.7)$ \\
& Root & 28.33 & 1.0 & $(10.8)$ \\
\hline \multirow{3}{*}{ Mature } & Whole plant & 15.93 & 9.1 & $(100.0)$ \\
& Seed & 3.91 & 0.7 & $(8.0)$ \\
& Pod & 10.77 & 0.8 & $(8.4)$ \\
& Leaf & 43.86 & 5.0 & $(55.8)$ \\
& Petiole & 9.76 & 0.6 & $(6.7)$ \\
& Stern & 10.46 & 1.0 & $(10.6)$ \\
& Root & 21.27 & 1.0 & $(10.5)$
\end{tabular}




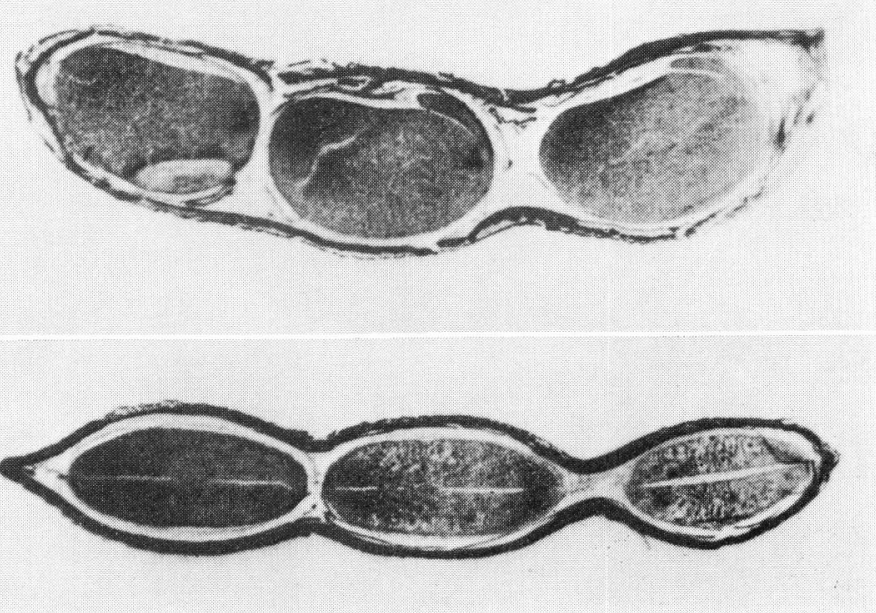

Fig. 1 Whole body autoradiogram of the soybean green seed.

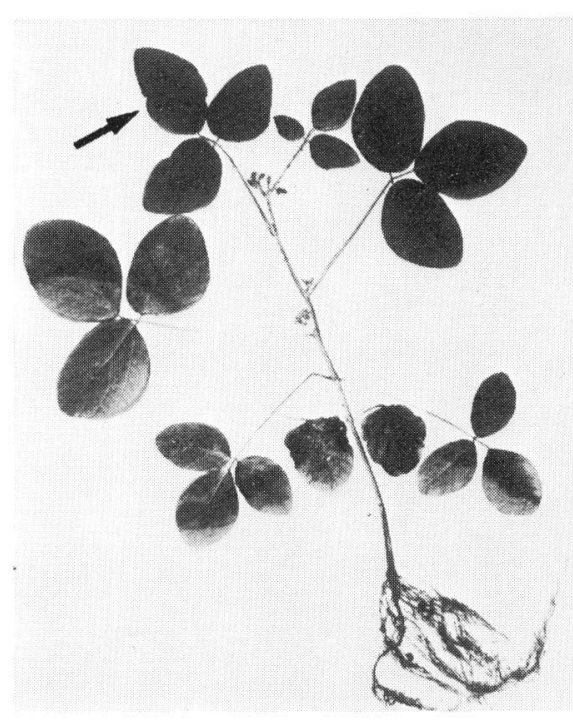

Photograph

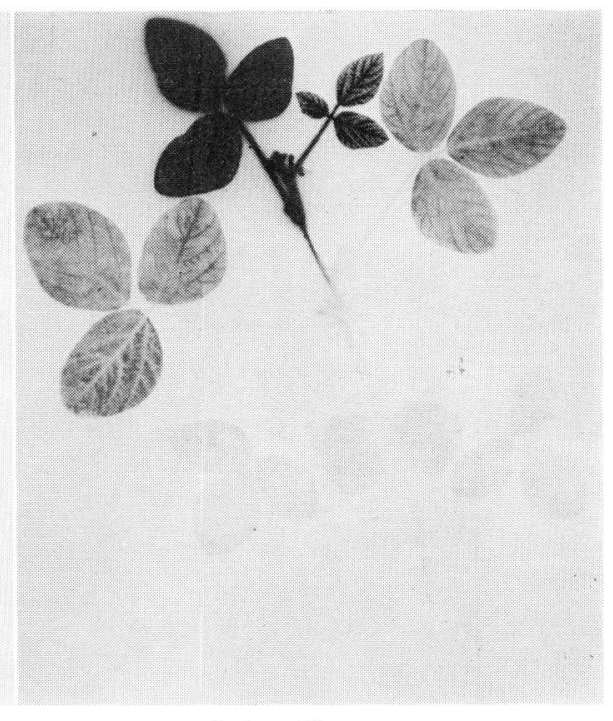

Autoradiogram

Fig. 2 Autoradiogram of the soybean plant treated topically with ${ }^{14} \mathrm{C}$-orbencarb on the upper surface of fifth-true leaf.

Arrow indicates the treated leaf.

dichloromethane extracts were identified by co-chromatography with the authentic compounds. At the same time, the fractions were treated chemically with $6 \mathrm{~N} \mathrm{HCl}$ at $85^{\circ} \mathrm{C}$ for $4 \mathrm{hr}$. Major metabolites were identified by gas chromatography (GC) in a sulfur mode using a Shimadzu 3BFp gas-chromatograph with a flame photometric detector before or after the methylation with diazomethane. In addition, provided that a sufficient amount of metabolites was obtained for identification, GC-MS was conducted in an EI (70 eV) or CI (isobutane) mode on a Shimadzu LKB-9000B mass spectrometer. 


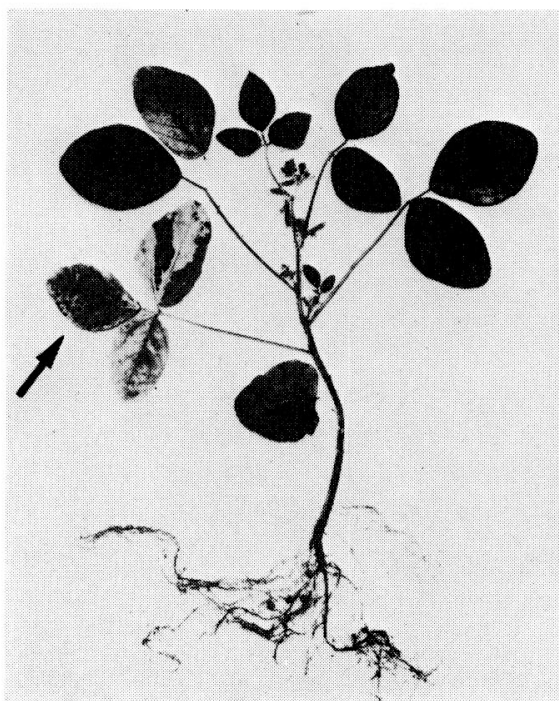

Photograph

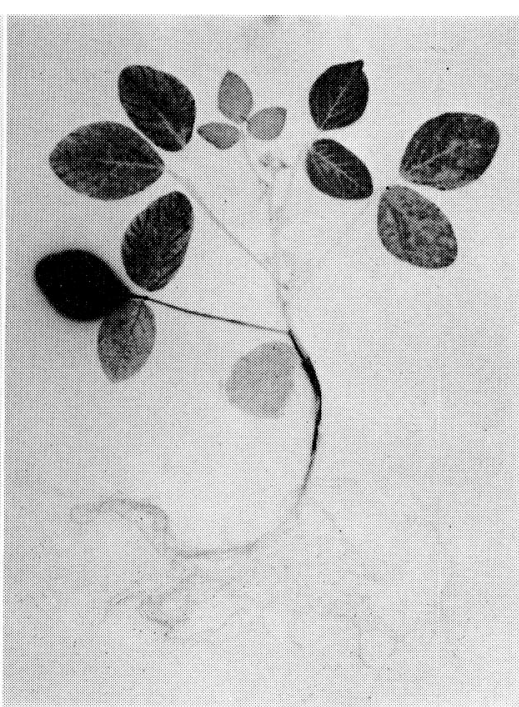

Autoradiogram

Fig. 3 Autoradiogram of the soybean plant treated topically with ${ }^{14} \mathrm{C}$-orbencarb on the upper surface of first-true leaf.

Arrow indicates the treated leaf.

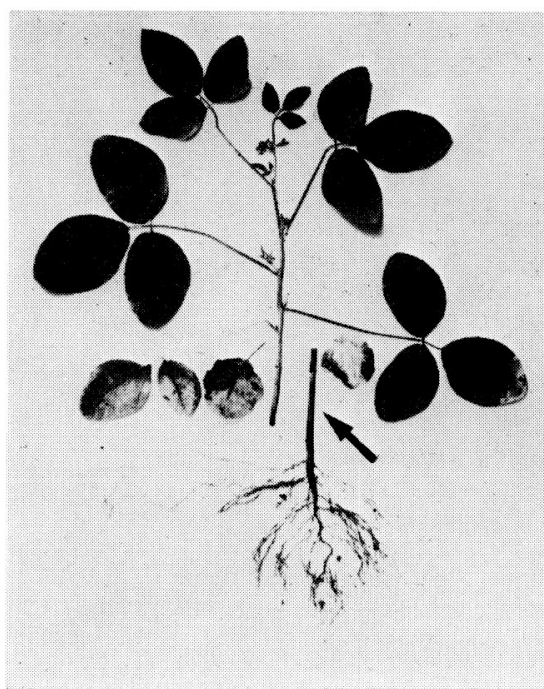

Photograph

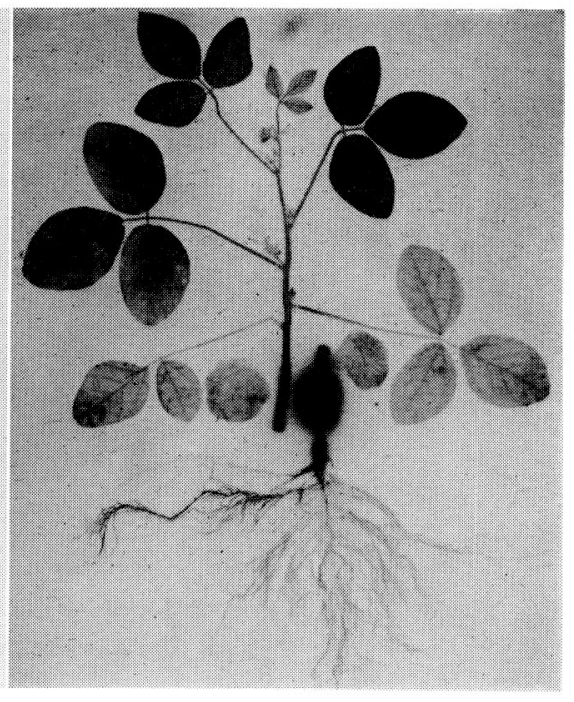

- Autoradiogram

Fig. 4 Autoradiogram of the soybean plant treated topically with ${ }^{14} \mathrm{C}$-orbencarb on the stem.

Arrow indicates the treated position.

\section{Radioassay}

Aliquots, usually $0.5 \mathrm{ml}$ of the extracts, were taken into vials and $0.5 \mathrm{ml}$ of toluene and 10 $\mathrm{ml}$ of scintillator (Scintisol ${ }^{\circledR}$ EX-H, Dojindo
Laboratories) were added. The autoradiograms of TLC plates were prepared and the regions corresponding to radioactive spots on TLC plates were scrapped into vials containing $1 \mathrm{ml}$ 
of methanol and $10 \mathrm{ml}$ of scintillator. Radioassay was done by an Aloka 673 liquid scintillation spectrometer. Seedlings were dried and contacted with Fuji X-ray film for auroradiography. For the whole body autoradiography, seeds with pods were frozen in an $8 \%$ sodium carboxymethylcellulose solution at $-20^{\circ} \mathrm{C}$, sectioned $40 \mu \mathrm{m}$ thick by an autocryotome (Type NA-200, Nakagawa Seisakusho) using Ullberg's method, ${ }^{2}$ and contacted with Sakura ${ }^{3} \mathrm{H}$-type X-ray film.

\section{RESULTS}

\section{Absorption and Translocation of ${ }^{14} \mathrm{C}$-Orben- carb in Soybean}

The absorption and translocation of radioactivity derived from ${ }^{14} \mathrm{C}$-orbencarb applied to the soil surface increased with time after seeding, suggesting that the absorption closely relates with development of the root system. The pattern of absorption and translocation at the early stage of treatment is shown in Table 2. The concentration of radioactivity in each part of the plant gradually increased with time: highest in the root, followed by the primary leaf, first-true leaf, second-true leaf and third-true leaf. Particularly, the radioactivity in the newly developed leaf was low compared to the older leaf.

The distribution of radioactivity at the flowering stage (30 days after seeding), green seed stage (62 days after seeding) and mature stage (84 days after seeding) is shown in Table 3. The plants at the flowering, green seed and mature stages absorbed $0.8,9.3$ and $9.1 \%$ of the applied dosage, respectively. The ratio of the translocation of radioactivity to the seed was 4.8 and $8.0 \%$ in the whole plant for the green seed and mature stages, respectively. The absorption amount was lowest in the seed. The absorption of radioactivity increased rapidly at the flowering stage, reached 9.3\% (10.34 ppm) at the green seed stage, and then decreased slightly towards the mature stage. As shown in Table 3, more than $50 \%$ of radioactivity in the plant was located in the leaves. The ratio of distribution at the mature stage was $55.8 \%$ in the leaves and $8.0 \%$ in seeds. As a total balance of applied radioactivity, the mature plant absorbed $9.1 \%$ of the dosage, the soil $27.5 \% \quad(0.93 \mathrm{ppm})$, and the remaining
$63.4 \%$ dissipated from the surface of soil or plant.

The whole body autoradiogram shows the distribution of radioactivity in a soybean plant at the green seed stage (Fig. 1). The radioactivity was distributed uniformly in the whole seed. The concentrations of radioactive compounds equivalent to orbencarb in the seeds at the green seed and mature stages were 1.61 and $3.91 \mathrm{ppm}$, respectively, and the ratios to the dosage were 0.4 and $0.7 \%$, respectively.

The translocation of radioactivity in the whole plant was examined by autoradiography. Three sites of the plant were treated: the upper surface of the fifth-true leaf, the first-true leaf and the stem base. The radioactivity was mainly translocated upwards. The downwards translocation was very small compared with the upwards movement (Figs. 2, 3 and 4).

\section{Metabolism Studies}

Plant metabolites at the flowering, green seed, mature stages and in hervested seeds were analyzed.

The data at the flowering stage are shown in Table 4. The radioactivity absorbed into the soybean plant was $14.9 \%$ in the dichloromethane-soluble fraction, $72.0 \%$ in the watersoluble fraction and the rest $13.1 \%$ in the unextractable residues. The ratio of the dichloromethane-soluble fraction to the watersoluble fraction was about 1 to 5 for each plant part. An example of TLC conducted with the dichloromethane-soluble fraction is shown in Fig. 5. Orbencarb, orbencarb sulfoxide, monodesethyl-orbencarb, didesethyl-orbencarb, $\mathrm{N}$ $\mathrm{CH}=\mathrm{CH}_{2}$-orbencarb, 4-OH-orbencarb, 5-OHorbencarb, 2-Cl-BZ alc, 2-Cl-benzoic acid, 2$\mathrm{Cl}-\mathrm{BZ}-\mathrm{S}(\mathrm{O}) \mathrm{CH}_{3}$ and 2-Cl-BZ- $\mathrm{SO}_{2} \mathrm{CH}_{3}$ were tentatively identified by two dimensional co-TLC with authentic compounds. Other unidentified compounds and an origin substance were also detected on TLC plate. The origin substance was further developed with polar solvent system $\mathrm{C}$ and several unknown metabolites were separated. Water-soluble metabolites such as 2-Cl-BZ-SO ${ }_{3} \mathrm{H}$ and several conjugates were isolated. 2-Cl-BZ-SO $\mathrm{S}_{3} \mathrm{H}$ made up $41 \%$ of radioactivity in the plant. When the watersoluble fraction was treated with enzymes or acids, 2-Cl-BZ alc and 2-Cl-benzoic acid were 
Table 4 Percent of orbencarb and its metabolites in the soybean plant at the flowering stage.

\begin{tabular}{|c|c|c|c|c|c|}
\hline Fractions & Metabolites & Root & Stem & Petiole+leaf & Whole plant \\
\hline \multicolumn{2}{|c|}{ Dichloromethane-soluble } & 3.4 & 2.7 & 8.8 & 14.9 \\
\hline & Orbencarb (OC) & 0.8 & 0.6 & 0.1 & 1.6 \\
\hline & OC sulfoxide & $<0.1$ & $<0.1$ & - & $<0.1$ \\
\hline & Monodesethyl-OC & 0.5 & 0.3 & 0.1 & 0.9 \\
\hline & Didesethyl-OC & - & - & 0.1 & 0.1 \\
\hline & $\mathrm{N}-\mathrm{CH}=\mathrm{CH}_{2}-\mathrm{OC}$ & $<0.1$ & $<0.1$ & $<0.1$ & 0.1 \\
\hline & $4-\mathrm{OH}-\mathrm{OC}$ & - & - & - & - \\
\hline & 5-OH-OC & - & $<0.1$ & $<0.1$ & $<0.1$ \\
\hline & 2-Cl-BZ alc & $<0.1$ & 0.1 & $<0.1$ & 0.2 \\
\hline & 2-Cl-Benzoic acid & $<0.1$ & $<0.1$ & 0.2 & 0.3 \\
\hline & 2-Cl-BZ-S $(\mathrm{O}) \mathrm{CH}_{3}$ & $<0.1$ & 0.1 & 0.1 & 0.2 \\
\hline & 2-Cl-BZ- $\mathrm{SO}_{2} \mathrm{CH}_{3}$ & 0.1 & 0.3 & 6.8 & 7.1 \\
\hline & Unknown-1 & 0.1 & - & - & 0.1 \\
\hline & Unknown-2 & 0.1 & 0.1 & 0.2 & 0.3 \\
\hline & Unknown-3 & $<0.1$ & $<0.1$ & 0.1 & 0.1 \\
\hline & Origin & 1.6 & 1.1 & 1.1 & 3.9 \\
\hline \multirow[t]{7}{*}{ Water-solub } & & 19.3 & 12.4 & 40.3 & 72.0 \\
\hline & ${ }^{14} \mathrm{C}$-Aglycones & & & & \\
\hline & 2-Cl-BZ alc & 3.2 & 4.1 & 6.5 & 13.6 \\
\hline & 2-Cl-Benzoic acid & 1.1 & 0.9 & 1.2 & 3.0 \\
\hline & Unknowns & 0.8 & 1.0 & 1.2 & 3.0 \\
\hline & 2-Cl-BZ-SO ${ }_{3} \mathrm{H}$ & 6.9 & 2.6 & 29.5 & 41.0 \\
\hline & Aqueous & 7.3 & 3.8 & 1.9 & 11.4 \\
\hline \multicolumn{2}{|c|}{ Bound residue } & 1.0 & 2.0 & 10.1 & 13.1 \\
\hline \multicolumn{2}{|c|}{ Total } & 23.7 & 17.1 & 59.2 & 100.0 \\
\hline
\end{tabular}

$2 \longrightarrow$ benzene-ethyl acetate $(9: 1)$

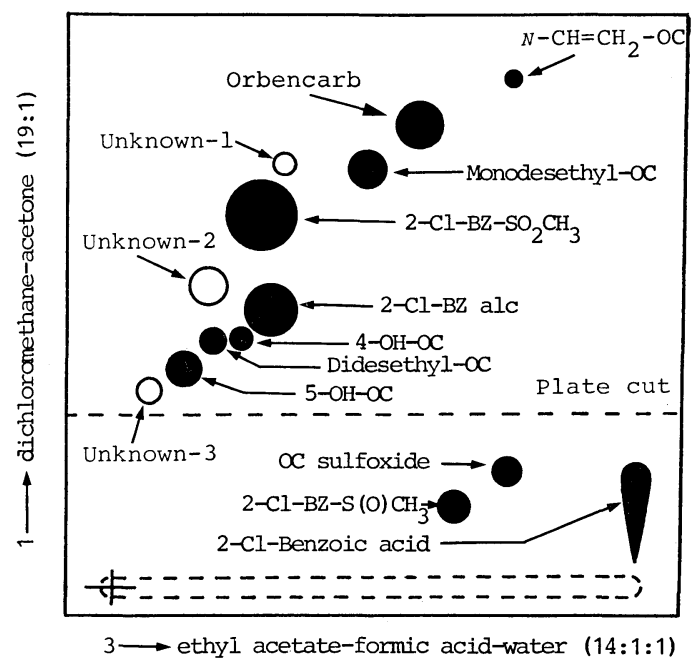

Fig. 5 Thin layer chromatogram of ${ }^{14} \mathrm{C}$-compounds in the dichloromethane-soluble fraction of the soybean plant. isolated as ${ }^{14} \mathrm{C}$-aglycons.

The data at the green seed stage are shown in Table 5. The radioactivity in the plant was $13.4 \%$ in the dichloromethane-soluble fraction, $77.6 \%$ in the water-soluble fraction and the rest $9.0 \%$ in the unextractable residues. The dichloromethane-soluble fraction contained the same compounds as identified at the flowering stage. Other metabolites except 2-Cl-BZ$\mathrm{SO}_{2} \mathrm{CH}_{3}$ were at a very low level. 2-Cl-BZ$\mathrm{SO}_{3} \mathrm{H}$ was also the main metabolite in the water-soluble fraction. 2-Cl-BZ alc and 2-Clbenzoic acid were identified as aglycones when treated with the enzyme. 2-Cl-BZ-Cys was also detected although very small in volume.

The data at the mature stage are shown in Table 6 . The radioactivity absorbed into the plant was $8.2 \%$ in the dichloromethane-soluble fraction, $77.9 \%$ in the water-soluble fraction, and the rest $13.9 \%$ in the unextractable residues. Several minor metabolites detected at the flowering stage were also observed at this 
Table 5 Percent of orbencarb and its metabolites in the soybean plant at the green seed stage.

\begin{tabular}{|c|c|c|c|c|c|c|c|c|}
\hline Fractions & Metabolites & Root & Stem & Petiole & Leaf & Pod & Seed & Whole plant \\
\hline \multicolumn{2}{|c|}{ Dichloromethane-soluble } & 1.7 & 1.0 & 0.5 & 7.9 & 0.8 & 1.5 & 13.4 \\
\hline & Orbencarb (OC) & 0.2 & $<0.1$ & $<0.1$ & $<0.1$ & $<0.1$ & - & 0.2 \\
\hline & OC sulfoxide & $<0.1$ & $<0.1$ & - & - & - & - & $<0.1$ \\
\hline & Monodesethyl-OC & 0.1 & $<0.1$ & $<0.1$ & $<0.1$ & $<0.1$ & - & 0.2 \\
\hline & Didesethyl-OC & $<0.1$ & - & - & - & - & - & $<0.1$ \\
\hline & $N-\mathrm{CH}=\mathrm{CH}_{2}-\mathrm{OC}$ & - & $<0.1$ & - & - & - & - & $<0.1$ \\
\hline & $4-\mathrm{OH}-\mathrm{OC}$ & - & - & - & - & - & - & - \\
\hline & $5-\mathrm{OH}-\mathrm{OC}$ & - & - & - & - & - & - & - \\
\hline & 2-Cl-BZ alc & $<0.1$ & $<0.1$ & $<0.1$ & $<0.1$ & 0.1 & - & 0.1 \\
\hline & 2-Cl-Benzoic acid & 0.1 & $<0.1$ & $<0.1$ & 0.2 & 0.1 & $<0.1$ & 0.4 \\
\hline & 2-Cl-BZ-S(O) $\mathrm{CH}_{3}$ & $<0.1$ & $<0.1$ & - & - & $<0.1$ & - & 0.1 \\
\hline & 2-Cl-BZ- $\mathrm{SO}_{2} \mathrm{CH}_{3}$ & 0.1 & 0.1 & $<0.1$ & 1.7 & 0.4 & 0.5 & 2.9 \\
\hline & Unknown-1 & - & - & - & - & - & - & - \\
\hline & Unknown-2 & 0.1 & $<0.1$ & - & 0.2 & $<0.1$ & - & 0.3 \\
\hline & Unknown-3 & $<0.1$ & $<0.1$ & $<0.1$ & 0.2 & $<0.1$ & - & 0.2 \\
\hline & Others & - & - & - & - & - & 0.1 & 0.1 \\
\hline & Origin & 1.1 & 0.7 & 0.4 & 5.6 & 0.2 & 0.8 & 8.9 \\
\hline \multirow[t]{8}{*}{ Water-soluk } & & 6.0 & 7.6 & 3.4 & 49.7 & 8.0 & 2.9 & 77.6 \\
\hline & ${ }^{14} \mathrm{C}$-Aglycones & & & & & & & \\
\hline & 2-Cl-BZ alc & 1.1 & 2.0 & 1.1 & 9.3 & 1.2 & 0.5 & 15.1 \\
\hline & 2-Cl-Benzoic acid & 0.5 & 0.9 & 0.4 & 2.4 & 0.2 & $<0.1$ & 4.5 \\
\hline & Unknowns & 0.4 & 0.8 & 0.3 & 0.4 & 0.2 & 0.3 & 2.4 \\
\hline & 2-Cl-BZ- $\mathrm{SO}_{3} \mathrm{H}$ & 1.4 & 0.7 & 0.8 & 33.2 & 4.3 & 0.7 & 41.3 \\
\hline & 2-Cl-BZ-Cys & 0.1 & 0.2 & 一 & - & - & - & 0.3 \\
\hline & Aqueous & 2.5 & 3.0 & 0.8 & 4.4 & 2.1 & 1.3 & 14.0 \\
\hline \multicolumn{2}{|c|}{ Bound residue } & 3.1 & 1.1 & 0.4 & 3.5 & 0.5 & 0.4 & 9.0 \\
\hline \multicolumn{2}{|c|}{ Total } & 10.8 & 9.7 & 4.3 & 61.1 & 9.3 & 4.8 & 100.0 \\
\hline
\end{tabular}

Table 6 Percent of orbencarb and its metabolites in the soybean plant at the mature stage.

\begin{tabular}{|c|c|c|c|c|c|c|c|c|}
\hline Fractions & Metabolites & Root & Stem & Petiole & Leaf & Pod & Seed & Whole plant \\
\hline \multicolumn{2}{|c|}{ Dichloromethane-soluble } & 1.2 & 1.0 & 0.4 & 2.0 & 0.5 & 3.1 & 8.2 \\
\hline & Orbencarb (OC) & 0.2 & $<0.1$ & - & - & - & - & 0.2 \\
\hline & OC sulfoxide & $<0.1$ & - & - & - & - & - & $<0.1$ \\
\hline & Monodesethyl-OC & 0.1 & $<0.1$ & - & - & - & - & 0.1 \\
\hline & Didesethyl-OC & $<0.1$ & - & - & - & - & - & $<0.1$ \\
\hline & $\mathrm{N}-\mathrm{CH}=\mathrm{CH}_{2}-\mathrm{OC}$ & - & $<0.1$ & - & - & - & - & $<0.1$ \\
\hline & 4-OH-OC & $<0.1$ & - & - & - & - & - & $<0.1$ \\
\hline & 5-OH-OC & $<0.1$ & - & - & - & - & - & $<0.1$ \\
\hline & 2-Cl-BZ alc & $<0.1$ & $<0.1$ & $<0.1$ & 0.1 & $<0.1$ & $<0.1$ & 0.2 \\
\hline & 2-Cl-Benzoic acid & 0.1 & $<0.1$ & $<0.1$ & 0.1 & $<0.1$ & 0.5 & 0.8 \\
\hline & 2-Cl-BZ-S(O) $\mathrm{CH}_{3}$ & $<0.1$ & - & - & - & - & - & $<0.1$ \\
\hline & 2-Cl-BZ- $\mathrm{SO}_{2} \mathrm{CH}_{3}$ & $<0.1$ & $<0.1$ & $<0.1$ & 0.2 & 0.1 & 0.2 & 0.5 \\
\hline & Unknown-1 & $<0.1$ & $<0.1$ & - & - & - & - & $<0.1$ \\
\hline & Unknown-2 & - & - & - & 0.1 & - & - & 0.1 \\
\hline & Unknown-3 & - & - & - & 一 & - & - & - \\
\hline & Others & - & - & - & - & - & 0.1 & 0.1 \\
\hline & Origin & 0.7 & 0.9 & 0.4 & 1.5 & 0.4 & 2.3 & 6.2 \\
\hline
\end{tabular}


Table 6 (continued)

\begin{tabular}{llrrrrrrr}
\hline Fractions & Metabolites & Root & Stem & Petiole & Leaf & Pod & Seed & Whole plant \\
\hline Water-soluble & & 5.1 & 8.5 & 5.5 & 50.2 & 4.8 & 3.8 & 77.9 \\
& 14C-Aglycones & & & & & & & \\
& 2-Cl-BZ alc & 0.9 & 2.0 & 1.9 & 12.7 & 0.5 & 0.7 & 18.8 \\
& 2-Cl-Benzoic acid & 0.3 & 0.8 & 0.4 & 1.8 & 0.2 & 0.1 & 3.5 \\
& Unknowns & 0.3 & 0.3 & 0.2 & 0.4 & $<0.1$ & 0.5 & 1.7 \\
& 2-Cl-BZ-SO ${ }_{3} \mathrm{H}$ & 0.8 & 0.2 & 1.0 & 29.6 & 1.6 & 0.5 & 33.8 \\
Bound residue & Aqueous & 2.8 & 5.2 & 2.0 & 5.7 & 2.5 & 2.0 & 20.1 \\
Total & & 4.2 & 1.1 & 0.8 & 3.6 & 3.1 & 1.1 & 13.9 \\
& & 10.5 & 10.6 & 6.7 & 55.8 & 8.4 & 8.0 & 100.0
\end{tabular}

Table 7 Concentration and percent of orbencarb metabolites in the soybean seed.

\begin{tabular}{|c|c|c|c|c|c|}
\hline \multirow{2}{*}{ Fractions } & \multirow{2}{*}{ Metabolites } & \multicolumn{2}{|c|}{ Green seed (62 days) } & \multicolumn{2}{|c|}{ Mature seed (84 days) } \\
\hline & & $(\mathrm{ppm})^{\mathrm{a})}$ & $(\%)$ & $(\mathrm{ppm})^{\mathrm{a})}$ & $(\%)$ \\
\hline \multicolumn{2}{|c|}{ Acetonitrile-soluble } & 0.100 & 6.2 & 0.042 & 1.1 \\
\hline & 2-Cl-BZ alc & 一 & 一 & 0.003 & 0.1 \\
\hline & 2-Cl-Benzoic acid & - & - & 0.001 & $<0.1$ \\
\hline & 2-Cl-BZ- $\mathrm{SO}_{2} \mathrm{CH}_{3}$ & 0.097 & 6.0 & 0.030 & 0.8 \\
\hline & Others & $<0.001$ & $<0.1$ & $<0.001$ & $<0.1$ \\
\hline & Origin & 0.003 & 0.2 & 0.008 & 0.2 \\
\hline \multicolumn{2}{|c|}{ Hexane-soluble } & 0.008 & 0.5 & 0.033 & 0.8 \\
\hline \multicolumn{2}{|c|}{ Dichloromethane-soluble } & 0.382 & 23.8 & 1.452 & 37.2 \\
\hline & 2-Cl-BZ alc & - & - & 0.006 & 0.2 \\
\hline & 2-Cl-Benzoic acid & 0.015 & 0.9 & 0.266 & 6.8 \\
\hline & 2-Cl-BZ- $\mathrm{SO}_{2} \mathrm{CH}_{3}$ & 0.080 & 5.0 & 0.058 & 1.5 \\
\hline & Others & 0.021 & 1.3 & 0.001 & $<0.1$ \\
\hline & Origin & 0.266 & 16.6 & 1.121 & 28.7 \\
\hline \multirow[t]{7}{*}{ Water-solul } & & 0.966 & 60.1 & 1.826 & 46.7 \\
\hline & ${ }^{14} \mathrm{C}$-Aglycones & 0.290 & 18.0 & 0.603 & 15.4 \\
\hline & 2-Cl-BZ alc & 0.172 & 10.7 & 0.324 & 8.3 \\
\hline & 2-Cl-Benzoic acid & 0.012 & 0.7 & 0.056 & 1.4 \\
\hline & Unknowns & 0.106 & 6.6 & 0.223 & 5.7 \\
\hline & 2-Cl-BZ- $\mathrm{SO}_{3} \mathrm{H}$ & 0.244 & 15.2 & 0.243 & 6.2 \\
\hline & Aqueous & 0.432 & 26.9 & 0.980 & 25.1 \\
\hline \multicolumn{2}{|c|}{ Bound residue } & 0.150 & 9.4 & 0.553 & 14.2 \\
\hline \multicolumn{2}{|l|}{ Total } & 1.606 & 100.0 & 3.906 & 100.0 \\
\hline
\end{tabular}

a) Values are expressed by orbencarb eq./fresh weight.

stage. 2-Cl-BZ alc and 2-Cl-benzoic acid were found in the petiole, pod and seed. 2-Cl-BZ$\mathrm{SO}_{3} \mathrm{H}, 33.8 \%$, and conjugates of 2-Cl-BZ alc, $18.8 \%$, and 2-Cl-benzoic acid, $3.5 \%$, were found in the water-soluble fraction.

The ratio of the radioactivity in the seed to the total in the plant was $4.8 \%(1.606 \mathrm{ppm})$ for the green seed and $8.0 \%(3.906 \mathrm{ppm})$ for the mature seed. The greater parts of radioactivity in the seed were soluble in dichloromethane and water, and the radioactivity in the acetonitrile and hexane fractions were very low (Table 7). Orbencarb was not found in the seed. Metabolites soluble in dichloromethane occupied $23.8 \%$ of the total radioactivity for the green seed and $37.2 \%$ for the mature seed. 

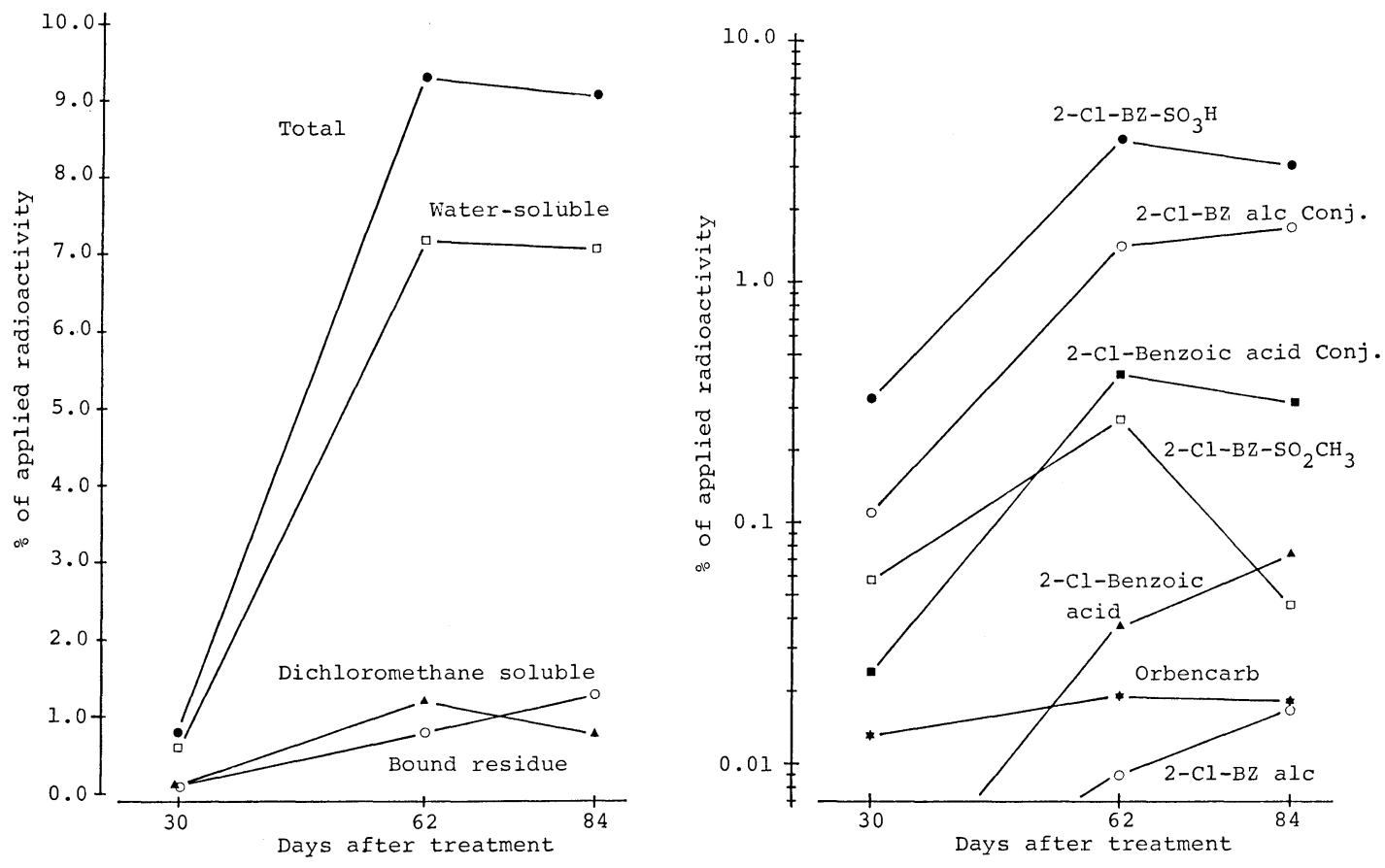

Fig. 6 Distribution of radioactivity of orbencarb and its metabolites in the soybean plant.

2-Cl-BZ alc, 2-Cl-benzoic acid and 2-Cl-BZ$\mathrm{SO}_{2} \mathrm{CH}_{3}$ were identified in the seed. The major metabolite in the acetonitrile fraction was 2$\mathrm{Cl}-\mathrm{BZ}-\mathrm{SO}_{2} \mathrm{CH}_{3}$. The water-soluble fraction contained several unidentified metabolites at a low level. The major metabolite in the watersoluble fraction was 2-Cl-BZ- $\mathrm{SO}_{3} \mathrm{H}$, whose content was $0.244 \mathrm{ppm}$ in green seeds and $0.243 \mathrm{ppm}$ in mature seeds. The water-soluble fraction, treated with enzymes, released 2-Cl$\mathrm{BZ}$ alc and 2-Cl-benzoic acid.

The main metabolites obtained in sufficient quantities for analysis were identified by GC or GC-MS during or after the methylation with diazomethane.

The time-course of metabolites in the plant is shown in Fig. 6. The radioactivity in the plant increased rapidly at the flowering stage, reached the maximum of $9.3 \%$ of the applied dosage at the green seed stage, and declined slightly towards the mature stage. Water-soluble metabolites composed of 70 to $80 \%$ of the total radioactivity, and both the dichloromethane- and water-soluble metabolites reached the maximum at the green seed stage and declined towards the mature stage. Unextractable residues, however, increased slightly at the mature stage. Orbencarb was detected at a very low level. The main metabolites, 2-Cl$\mathrm{BZ}-\mathrm{SO}_{3} \mathrm{H}$ and glycoside conjugates of 2-Cl-BZ alc and 2-Cl-benzoic acid, increased rapidly at the flowering stage, and leveled off at the green seed and mature stages.

\section{Degradation Products in Soil}

As shown in Table $8,27.5 \%$ of the applied radioactivity remained in the soil 84 days after treatment. In the soil, $0.252 \mathrm{ppm}$ of orbencarb corresponding to $7.4 \%$ of the applied dosage remained as a major component, and ten minor degradation products derived from ${ }^{14} \mathrm{C}$-orbencarb were identified by co-TLC with the authentic compounds. They were the same compounds as identified in the plant.

\section{DISCUSSION}

The absorption of radioactivity derived from ${ }^{14} \mathrm{C}$-orbencarb started just after seeding and increased in volume with time. The increase was especially rapid from the flowering to the 
Table 8 Concentration and percent of orbencarb and its degradation products in the soil 84 days after treatment of ${ }^{14} \mathrm{C}$-orbencarb (5 kg/ha, eq.) on the soil.

\begin{tabular}{|c|c|c|c|c|}
\hline Fractions & ${ }^{14} \mathrm{C}$-Compounds & $\begin{array}{c}\text { ppm, }{ }^{14} \mathrm{C} \text {-orbencarb } \\
\text { eq./soil }\end{array}$ & $\begin{array}{l}\% \text {, applied } \\
\text { radioactivity }\end{array}$ & $\begin{array}{c}\% \\
\text { in soil }\end{array}$ \\
\hline \multicolumn{2}{|c|}{ Dichloromethane-soluble } & 0.320 & 9.4 & 34.3 \\
\hline & Orbencarb (OC) & 0.252 & 7.4 & 27.0 \\
\hline & OC sulfoxide & 0.009 & 0.3 & 0.9 \\
\hline & Monodesethyl-OC & 0.019 & 0.6 & 2.0 \\
\hline & $2-\mathrm{OH}-\mathrm{OC}$ & 0.005 & 0.2 & 0.6 \\
\hline & $4-\mathrm{OH}-\mathrm{OC}$ & 0.002 & 0.1 & 0.2 \\
\hline & $5-\mathrm{OH}-\mathrm{OC}$ & 0.002 & 0.1 & 0.2 \\
\hline & 2-Cl-BZ alc & 0.001 & $<0.1$ & 0.1 \\
\hline & 2-Cl-Benzoic acid & 0.003 & 0.1 & 0.4 \\
\hline & 2-Cl-BZ-S(O) $\mathrm{CH}_{3}$ & 0.004 & 0.1 & 0.4 \\
\hline & 2-Cl-BZ- $\mathrm{SO}_{2} \mathrm{CH}_{3}$ & 0.016 & 0.5 & 1.7 \\
\hline & Others & 0.007 & 0.2 & 0.8 \\
\hline \multicolumn{2}{|c|}{ Water-soluble } & 0.018 & 0.6 & 2.0 \\
\hline & 2-Cl-BZ-SO ${ }_{3} \mathrm{H}$ & 0.003 & 0.1 & 0.4 \\
\hline & Others & 0.015 & 0.5 & 1.6 \\
\hline \multicolumn{2}{|c|}{ Bound residue } & 0.595 & 17.5 & 63.7 \\
\hline \multicolumn{2}{|c|}{ Total } & 0.933 & 27.5 & 100.0 \\
\hline
\end{tabular}

green seed stage, absorbing about $90 \%$ of the radioactivity during these stages. Orbencarb appeared only at a low level in the plant, suggesting that it was rapidly metabolized in either the plant or the soil, which is supported by separate metabolism studies of ${ }^{14} \mathrm{C}$ orbencarb in soybean seedlings in a culture solution $^{3)}$ and in soils under various conditions. ${ }^{1)}$ The degradation pattern of orbencarb in the soybean plant and the soil was similar, and some of the same compounds were detected in both the plant and the soil, suggesting that some of the metabolites found in the plant were the degradation products in the soil.

The metabolic fate of thiocarbamate herbicides has been reviewed. ${ }^{4,5}$ Several studies have been done on the translocation, metabolism and degradation of a substituted benzylthiocarbamate in plants, ${ }^{4-8}$ soils ${ }^{9-13)}$ and microorganisms. ${ }^{14)} \quad$ Nakamura et al. ${ }^{7)}$ examined the metabolism of benthiocarb, (thiobencarb) 4-chlorobenzyl isomer of orbencarb, in rice plants, and identified monodesethylbenthiocarb, didesethyl-benthiocarb, 4-chlorobenzyl alcohol, 4-chlorobenzoic acid and their hydroxylation products on the benzene ring as metabolites. The present experiment demonstrated that the metabolic pattern of orben- carb in soybean plants resembled qualitatively to that of benthiocarb.

The studies on the metabolism of benthio$\operatorname{carb}^{7)}$ and on the activation and detoxification mechanisms of thiocarbamate sulfoxides ${ }^{15-17}$ ) and sulfones ${ }^{18)}$ by glutathione (GSH)-S-transferase systems suggest that the following reactions may participate in the metabolism of orbencarb in soybean plants:

1) Orbencarb sulfoxide was produced by the oxidation of sulfur atom, followed by the cleavage of thioester linkage to form 2-Cl-BZ alc. The alcohol was conjugated or further oxidized to 2-Cl-benzoic acid, followed by conjugation reaction. A 2-chlorobenzylsulfenic acid intermediate was also produced from orbencarb sulfoxide and oxidized to 2-Cl-BZ$\mathrm{SO}_{3} \mathrm{H}$ or partly methylated at the sulfur atom to form 2-Cl-BZ-S $(\mathrm{O}) \mathrm{CH}_{3}$.

2) Hydrolysis of thioester linkage was followed by the $S$-methylation of the 2-chlorobenzylmercaptan intermediate to form 2-Cl$\mathrm{BZ}-\mathrm{SCH}_{3}$, and further oxidation of sulfur atom produced the corresponding sulfoxide and sulfone.

3) Monodesethyl- and didesethyl-orbencarb were produced by the desethylation of $N, N$ diethylcarbamoyl moiety of orbencarb. 

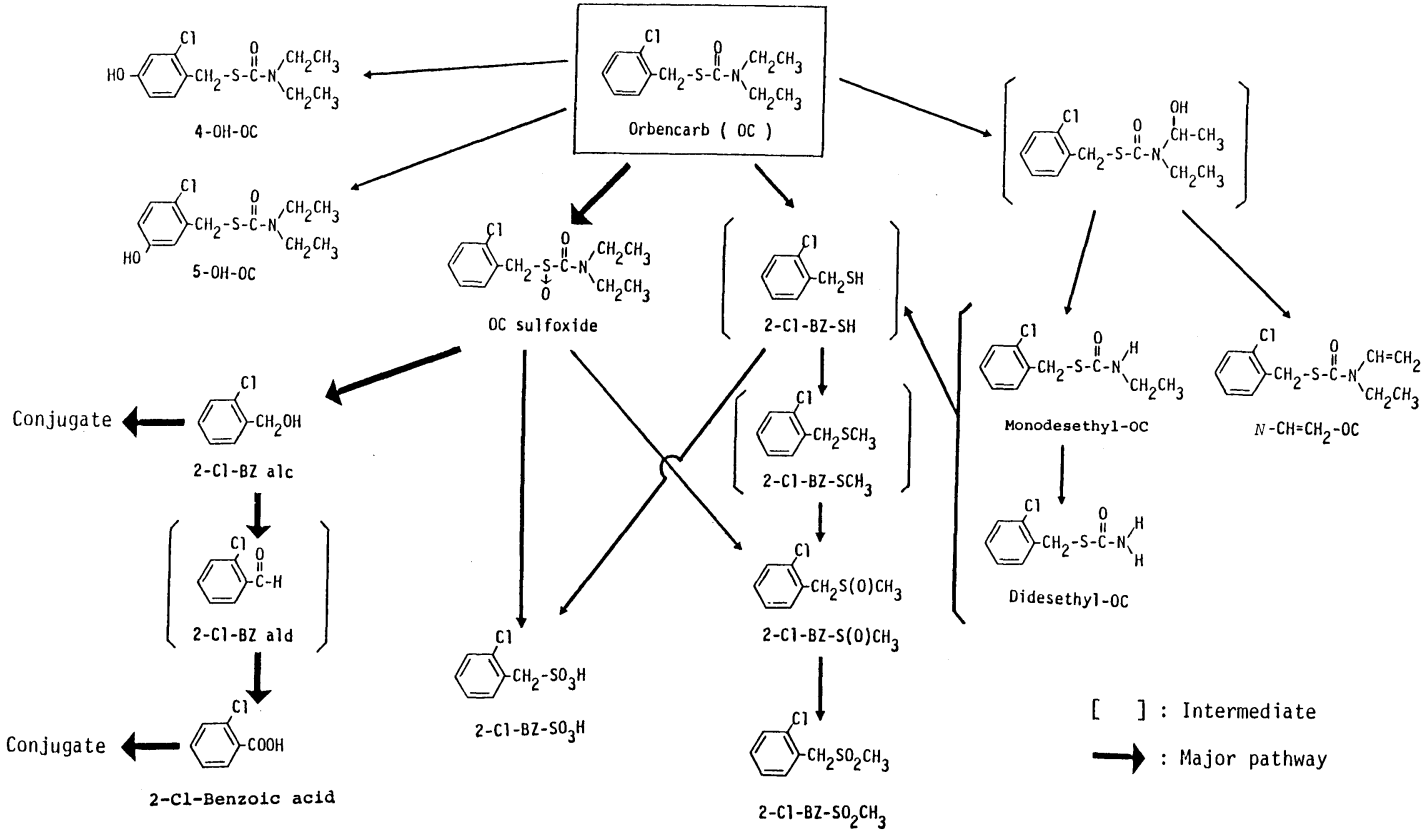

Fig. 7 Proposed metabolic pathways of orbencarb in the soybean plant.

4) 4- and 5-OH-orbencarb were produced by the hydroxylation at 4- or 5-position of the benzene ring of orbencarb, respectively.

Minor metabolites, $\mathrm{N}$ - $\mathrm{CH}=\mathrm{CH}_{2}$-orbencarb and 2-Cl-BZ-Cys, were isolated. The mechanisms for the formation of these compounds will be described in a separate paper. ${ }^{3)}$

By summarizing the aforementioned reactions, the metabolic pathways of orbencarb are proposed in Fig. 7.

\section{ACKNOWLEDGEMENTS}

The authors wish to express their thanks to Ihara Chemical Industry Co., Ltd. for the supply of authentic compounds and to Professor K. Ishizuka of Tsukuba University for his encouragement.

\section{REFERENCES}

1) M. Ikeda, T. Unai \& C. Tomizawa: J. Pesticide Sci. 11, 85 (1986)

2) S. Ullberg: Acta Radiol. Suppl. 118, 1 (1954)

3) T. Unai, M. Ikeda \& C. Tomizawa: J. Pesticide Sci. submitted

4) S. C. Fang: "Herbicides-Chemistry, Degradation and Mode of Action," ed. by P. C. Keárney \& D. D. Kaufman, Vol. I, Marcel Dekker Inc., New York, pp. 323-348, 1975

5) F. M. Ashton \& A. S. Crafts: "Mode of Action of Herbicides," John Wiley \& Sons Inc., New
York, pp. 303-327, 1981

6) Y. Nakamura, K. Ishikawa \& S. Kuwatsuka: Agric. Biol. Chem. 38, 1129 (1974)

7) Y. Nakamura, K. Ishikawa \& S. Kuwatsuka: Agric. Biol. Chem. 41, 1613 (1977)

8) A. Takahashi \& K. Ishizuka: Weed Res. Jpn. 30, 21 (1985)

9) K. Ishikawa, Y. Nakamura \& S. Kuwatsuka: J. Pesticide Sci. 1, 49 (1976)

10) Y. Nakamura, K. Ishikawa \& S. Kuwatsuka: J. Pesticide Sci. 2, 7 (1977)

11) K. Ishikawa, Y. Nakamura \& S. Kuwatsuka: J. Pesticide Sci. 2, 127 (1977)

12) S. Duah-Yentumi \& S. Kuwatsuka: Soil Sci. Plant Nutr. 26, 541 (1980)

13) K. Ishikawa, Y. Nakamura \& S. Kuwatsuka: J. Pesticide Sci. 5, 603 (1980)

14) L. A. Golovleva, A. L. Klysheva, M. Yu. Nefedova, B. P. Baskunov, A. M. Zyakun \& A. N. Ilyaletdinov: Izv. Akad. Nauk Kaz. SSR, Ser. Biol. 6, 23 (1980)

15) J. E. Casida, R. A. Gray \& H. Tilles: Science 184, 573 (1974)

16) J. E. Casida, E. C. Kimmel, H. Ohkawa \& R. Ohkawa: Pestic. Biochem. Physiol. 5, 1 (1975)

17) I. Schuphan, J. D. Rosen \& J. E. Casida: Science 205, 1013 (1979)

18) R. D. Carringer, C. E. Rieck \& L. P. Bush: Weed Sci. 26, 157 (1978) 


\section{要約}

\section{オルベンカルブのダイズにおける吸収，移行お} よび代謝

池田光政，右内忠昭，富澤長次郎 土壤表面に $5 \mathrm{~kg} / \mathrm{ha}$ の割合で発芽前土壤処理した ${ }^{14} \mathrm{C}$ オルベンカルブの植物への吸収量は生育に伴い增加し た. 開花期, 枝豆期および完熟期には処理した放射能量 の $0.8 ， 9.3$ 抢よび $9.1 \%$ が植物に吸収された。植物各 部分に吸収された放射能量は, 種子で最も低く, 葉で最
も高かった，オルベンカルブは水溶性代謝物に速やかに 代謝され，主要な代謝物として 2-chlorobenzyl alcohol, 2-chlorobenzoic acid, 2-chlorobenzylsulfonic acid 拉よび methyl 2-chlorobenzylsulfone が同定された. 2-chlorobenzyl alcohol と 2-chlorobenzoic acid は抱合体としても 存在していた。そのほか, orbencarb-sulfoxide, monodesethyl-orbencarb, didesethyl-orbencarb, $N$-ethyl- $N$ vinyl-orbencarb, 4-hydroxy-orbencarb, 5-hydroxy-orbencarb 抒よび 2-chlorobenzylsulfonic acid が同定された. 